\title{
Enquêtemaand
}

A

fgelopen maand vroegen we in 2 enquêtes naar jullie mening en ervaringen: over agressie en over de psychische gevolgen na de (eerste) coronapiek. In dit nummer staan de belangrijkste conclusies opgetekend. Zo vulden 2000 verpleegkundigen de enquête over agressie in. En bijna de helft daarvan gaf aan het afgelopen jaar met agressie te maken hebben gehad. Vooral met verbale agressie. Met fysieke agressie heeft ruim $26 \%$ wekelijks mee te maken. In België is de situatie niet veel anders. Daar ervaart bijna $90 \%$ van de ziekenhuisverpleegkundigen en $78 \%$ van de thuisverpleegkundigen verbale of fysieke agressie. Heftige cijfers. Het lijkt bijna wel alsof agressie bij het vak hoort. Maar dat is natuurlijk niet acceptabel. En dus is het van belang dat je het type agressie herkent en er je benadering op af kunt stemmen. Daarom besteden we daar in het artikel op pagina 18 , op de website en in een webtv-uitzending uitgebreid aandacht aan. Zaak is de angel te vinden, de emotie te erkennen en te begrenzen. Helaas komt agressie ook steeds vaker voor in deze akelige coronatijd. Discussies met familie over het dragen van een mondkapje in de ziekenhuisgangen bijvoorbeeld, of het wel of niet toelaten van familie bij covid-19-patiënten, ook die kunnen agressie uitlokken.

Bijna 3000 Nursing-lezers namen deel aan de enquête over de psychische gevolgen van de (eerste) coronapiek. De redactie wilde weten hoe het ging met al die verpleegkundigen die zich zo hard hadden ingezet tijdens de (eerste) coronapiek. En toen het aantal besmettingen weer begon op te lopen, lag de vraag voor de hand in hoeverre verpleegkundigen zich voorbereid voelden op een eventuele tweede golf. Conclusie? De helft van de verpleegkundigen voelt zich er niet klaar voor. Sterker nog, velen voelen zich nog altijd gespannen en kampen met slapeloosheid en sombere gevoelens.

Wij als redactie schrokken ervan. En wij niet alleen. De resultaten van deze enquête werden ook opgepikt door landelijke media. Wijkverpleegkundige Kim de Groot, lid van onze redactionele adviesraad, kwam hierover breed aan het woord in zowel het NOS Journaal, Radio 1 als Hart van Nederland. En daarmee stond Nursing niet alleen landelijk op de kaart, maar hebben we met elkaar ook onze bezorgdheid geuit over de draagkracht van al die verpleegkundigen die er straks weer moeten staan, mocht covid-19 opnieuw toeslaan. Hopelijk ook een krachtig signaal naar de (Nederlandse) regering, die er (na de vele schandalige stemmingsdebacles) kennelijk nog altijd vanuit gaat dat werken in de zorg liefdewerk oud papier mag zijn. Daar worden wij nou 'agressief' van. Of nou ja, 'teleurgesteld' dan.

\section{Alexia Hageman}

\section{Hoofdredacteur Nursing}

Alexia.Hageman@bsl.nl

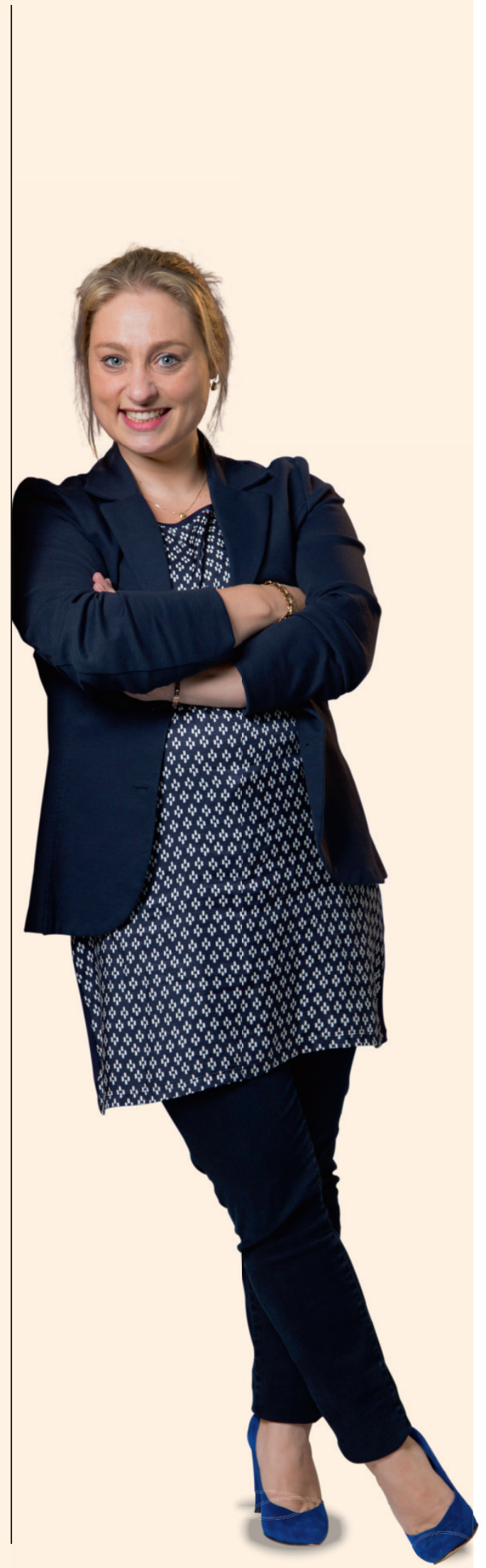

september 2020 I nursing 